\title{
短半減期 RI 化合物の凍結全身オートラジオグラフィ
}

\author{
柴 田 浩* \\ 放射線医学総合研究所 \\ 千葉市㞣川4-9-1 \\ 1975年 8 月11日 受理
}

\section{1. 緒言}

凍結全身オートラジオグラフィは, S. Ullberg'3) が 提唱して以来, 放射性同位元素 (RI) の生体内挙動を 調べる有用な方法の一つとして多くの研究に利用され てきた。本法は従来の方法に比べいくつかのすぐれた 点があるが，同時に欠点もある。凍結全身オートラジ オグラフィは，通常，動物に RI の投与 動物の凍結 凍結ブロックの作成 $\rightarrow$ 切片の作成 $\rightarrow$ 切片の凍結翰燥 $\rightarrow \mathrm{X}$ 線フィルムに露出 $\rightarrow$ 現像 $\rightarrow$ オートラジオグラムと いうように種々の技術的な過程がある。一般に良好な 切片標本を得るには, 動物の凍結一凍結ブロックの作 成および涷結ブロックー切片の作成の間にそれぞれ冷 凍庫中に一晚置き, 試料温度の均一化をはかる。また， 凍結乾燥には冷気強制循環方式の冷凍庫を用いても 24 時間くらいを要する。さらに，露出時間も必要であ る。このように凍結全身オートラジオグラフィは結果 を得るまでにある時間を要するといらのが欠点の一つ である。

一方, 核医学方面で使用する RI は, 被曝線量の軽 減を目的として半減期の短い短寿命のものに移行して きた。これらを使用するさい，当然これらの生体内挙 動関する実験的なデータが必要である。オートラジ オグラムも一つの有効なデータであるが，短寿命 RI では，常法に準じて行なえばその放射能は滅衰してし まい,オートラジオグラムは得られない。従って，オ 一トラジオグラムの作成過程の時間の短縮化が必要で あるが，これにはさまざまな技術的な困難が伴うため， 短寿命 RI のオートラジオグラフィに関する研究はあ まり行なわれていない。たと兊ば ${ }^{9{ }^{9}} \mathrm{~T} \mathrm{~T}$ の標識化合物 は現在核医学方面で最も多く利用されているが，全身 オートラジオグラフィによる実験的な研究報告1), 2) は 少ない。また，これらの報告では，オートラジオグラ フィの技法について詳しい情報を提供していない。 そこで, 短寿命 RI (とくに半減期が $2 \sim 6$ 時間の ものを対象としている）の全身オートラジオグラムを
得る方法を明らかにする目的で本研究を行なった。す なわち，短寿命 RI として ${ }^{99 m} \mathrm{Tc}$ (半減期 : 6.04時間), 供試動物としてマウスを使用し，全身オートラジオグ ラフィおよび定量実験を行ない，短寿命 RI の凍結全 身オートラジオグラフィの可能性について検討した。

\section{2. 実験材料および方法}

1）供試動物

ddY系雄マウス, 80 90日令, 体重28〜32 g のもの を供試した。実験供試数はオートラジオグラフィ実験 では 1 群 2 匹，定量実験では 1 群 6 匹を用いた。

2）供試 RI

$\mathrm{Na}^{9 s m} \mathrm{TcO}_{4}$ 注射液(過テクネチウム酸ナトリウム注 射液, 第一ラジオアイソトープ研究所製, 放射能濃度 : 検定時 $5 \mathrm{mCi} / \mathrm{ml}$ )を用いた。オートラジオグラフィ害 験ではマウス 1 匹あたり $100 ， 250,500 \mu \mathrm{Ci} / 0.2 \mathrm{ml}$ を， 定量実験ではマウス $30 \mathrm{~g}$ あたり $20 \mu \mathrm{Ci} / 0.2 \mathrm{ml}$ を尾静脈 内に注射した。本報では注射60分後の分布について検 討した。

\section{3）オートラジオグラフィ}

切片試料の作成および露出は当研究室のあらかじめ 遮光を可能にした冷凍室 $\left(-20^{\circ} \mathrm{C}\right.$ をで冷却可能) 内で 行なった。まず, $-3^{\circ} \mathrm{C} \sim-5^{\circ} \mathrm{C}$ の冷凍室内で供試動 物の凍結から切片（厚さ $40 \mu \mathrm{m}$ ) 作成までを連続的に 行ない，作成した切片試料を冷凍室内にある冷凍庫 $\left(-20^{\circ} \mathrm{C}\right)$ 飞一時保存した。ついで，冷凍室を $-15^{\circ} \mathrm{C}$ 以 下に冷却し ( $3 \sim 4$ 時間で冷却), 冷凍室内で切片試料 を乾燥せずにただちにX線フィルムとコンタクトでき るように処理した。ついで，冷凍室を遮光し，フィル ムカセット内で標本とX線フィルムをコンタクトし露 出した。露出中は冷凍室を $-15^{\circ} \mathrm{C} \sim-20$ Cに保った。 露出後, X線フィルムのみをカセットに入れて冷凍室

† Freezing Whole Body Autoradiography of Short Half Lived Radioactive Compounds. Hiroshi Shibata: National Institute of Radiological Sciences, Anagawa, Chiba-shi.

* 現所属 : 山口大学農学部, 山口书吉田1677-1 
より出し, 暗室内にて現像した。

\section{3. 実験結果および考察}

Fig. 1 に示すように， ${ }^{99 m} \mathrm{Tc}$ は甲状腺, 唾液腺, 胃, 食道に多く，ついで貯精のう，肝臓，血液，肺臓，膀 胱および尿道に, その注か骨髄, 腎葴, 脾藏等にみら れた。定量実験では (Table 1), ${ }^{99 m} \mathrm{~T}$ c の蔵器あたり の掑取量は肝臓, 唾液腺, 胃(壁拈よび内容), 血液が 多いが，臓器単位重量あたりの摂取率は甲状腺が著し く多く, ついで唾液腺, 胃が, さらに肝臓, 肺蔵, 血 液，㹂蔵，脾蔵がこれらについ圭。定量実験の結果は

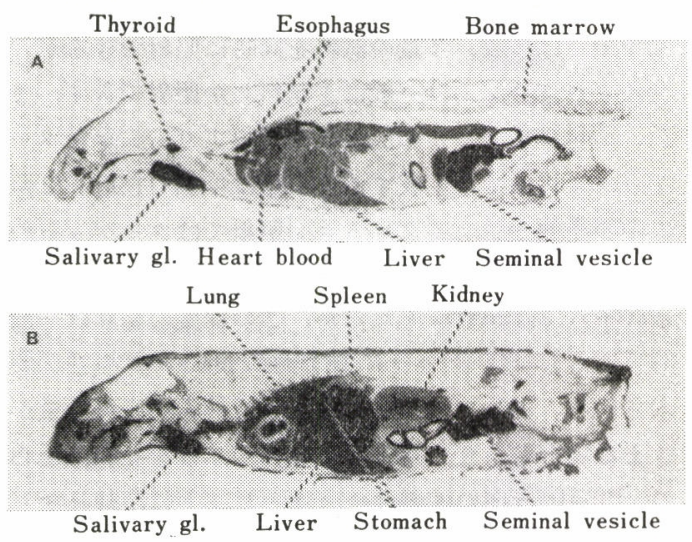

Fig. 1 Autoradiogram showing the distribution of radioactivity 60 minutes after intravenous injection of $\mathrm{Na}^{99 m} \mathrm{TcO}_{4}(\mathrm{~A}$ : Central axis aspect, B: Left lateral aspect).

Table 1 Organ distribution of ${ }^{99 m} \mathrm{Tc} 60$ minutes after intravenous injection

\begin{tabular}{l|c|c}
\hline & $\% / \mathrm{g}$ & $\% /$ whole organ \\
\hline Thyroid & $945^{*}$ & 3.28 \\
Salivary gl. & 113 & 20.6 \\
Stomach & 56.4 & 11.5 \\
Lung & 10.6 & 1.83 \\
Liver & 10.0 & 14.1 \\
Kidney & 7.28 & 2.62 \\
Spleen & 3.91 & 0.43 \\
Blood & 13.6 & 27.2 \\
\hline
\end{tabular}

* Value shows mean of six mice.

オートラジオグラムをよく支持した。

今回の実験では ${ }^{99 m} \mathrm{~T} c$ の投与量を検定時で100, 250, $500 \mu \mathrm{Ci} /$ 匹として，そのなかでは $500 \mu \mathrm{Ci} /$ 匹で良好な オートラジオグラムを得た。また RI の投与から露出 開始まで約 6 時間を要し，さらに露出時間は約 18 時間 であった。
切片の作成過程の時間の短縮化に伴う技術的問題で 重要なのは試料温度の均一性である。動物の凍結から 切片の作成までを連続的に行ならため, 試料温度が不 均一になりやすい。試料温度が不均一だと良好な切片 標本が得られないので，この点には十分に注意すべき である。

今回の実験では切片標本は乾燥せずー $15^{\circ} \mathrm{C} \sim-20^{\circ} \mathrm{C}$ の冷凍室で露出した。凍結乾燥時間の短縮化にも努力 すべきであるが，オートラジオグラフィの全過程の時 間の短縮化には乾燥せずにただちに露出することが最 も重要であろら。それには凍結切片を溶かすことなく フィルムに露出できる方法にくららをこらすべきであ ろら。

今回の実験経験から，動物の凍結から露出可能な標 本の作成まで 2 時間くらいにすることが可能であるこ とがわかった。一般に半減期の短い RI を臨床に使用 する場合は短時間で目的が達成できるものでありこ れらの実験的検討も短時間で良いことになる。従って 標本作成後ただちに露出可能な設備があれば, 半減期 が $2 \sim 3$ 時間の RI でも約 1 半減期で露出が開始でき るので, これらの RI そついてもオートラジオグラフ ィが可能と思われる。をた, 半減期のもら少し長い RI については動物への投与量の減少が可能とならら。 さらに, 短半減期の RI では放射能の減衰により露出 不足が起こりらるが，これには高感度のX線フィルム を使用することにより解決できよう。

通常, オートラジオグラムの臓器の識別にはその切 片標本も利用するが，今回のような場合はオートラジ オグラムに使用するものの隣接切片を乾燥しておき, これを利用すれぱよい。

\section{4. 結 論}

${ }^{99 m} \mathrm{~T}$ c 抢よびマウスを使用し凍結全身オートラジオ グラフィに要する時間の短縮化およびこれに伴う技術 的問題について検討し，半減期が $2 \sim 6$ 時間のよらな 短寿命 RI でも, 凍結全身オートラジオグラフィが可 能であることを明らかにした。

\section{文献}

1) Cohen, Y., Rebut-Bonneton, C., Roucayrol, J.C.: Nucl.-Med., 12, 225 31 (1973)

2) Doppelfeld, E., Kutzim, H.: Radiol., 14, $82 \sim 85$ (1974)

3) Ulberg, S.: Proc. Second U.N. Int. Conf. Peaceful Uses of Atomic Energy, 24, 248 54 (1958) 